Reflexive and Reasoned Religious Nationalism: the exploratory case of Russia

\title{
Edwin Bacon
}

Reader in International Politics, University of Lincoln (from 24 March 2018)

Before that:

Department of Politics

Birkbeck, University of London

Malet Street

London

WC1E 7HX

UK

e.bacon@,bbk.ac.uk

Telephone 1: +44 1522754109

\begin{abstract}
.
Nationalism theory has long acknowledged that in its relation to nationalism, 'religion' can refer both to a reflexive identity attached to a people group, and to an articulated and reasoned valuebased position. Even this bifurcation remains insufficiently precise. Religio-nationalisms reasoned expatria — that is, beginning with the nationalist and proceeding from there to incorporate religion — tend towards values of exclusivity, division, and animosity to 'the other'. They have been charged with 'hijacking' religion as an identity whilst being at odds with members and leaders of that religion's practicing community. The exploratory case of the relationship between Russian Orthodoxy and Russian nationalism allows a comparison of ex patria religio-nationalism with its ex religio counterpart. It confirms to a large extent the hypothesis that reasoned religio-nationalism that begins with the religious and proceeds to the nationalist favors in contrast less antagonistic emphases such as inclusivity and benevolence.
\end{abstract}


Western democracies are experiencing a new wave of right-wing populism that seeks to mobilise religion for its own ends'. So claimed the publisher's description of a 2016 book, Saving the People, edited by Nadia Marzouki, Duncan McDonnell, and Olivier Roy. If religious identity can be — to use the verb found in that book's sub-title— 'hijacked' by groups for whom it serves primarily as a marker of national identity, what does this mean for analysis of the relationship between religion and nationalism? If we accept that some right-wing populists 'hijack religion' to bolster their nationalist movements despite the objections of the religion's leaders and many practicing adherents, then what do we count as 'religion' when analysing such cases? Without further delineation the category 'religion' in relation to nationalism diminishes in analytical precision and utility.

Analyzing existing theoretical literature, we can generalize that the relationship between religion and nationalism has both a reflexive_or instinctual_aspect, stemming from long-standing popular overlap of a people and their faith, and a reasoned—or intellectual—aspect developed by theologians, nationalists, and others as a worked-out justification for the connection between nation and religion. Using Russia and Russian Orthodoxy as an exploratory case, this article theorizes that within reasoned justifications of the relationship between religion and nationalism, differentiation can further be made between expatria reasoning that begins with the national and proceeds to the religious, and ex religio reasoning that begins with the religious and proceeds to the national. It is further hypothesized that expatria reasoning tends towards a more axiologically divisive stance than ex religio reasoning.

\section{Reflexive and Reasoned Religio-Nationalism}

Anthony D. Smith has argued that a full understanding of nationalism requires engagement with those 'sacred sources' that pre-date the modern state and are formative of a nation $(2003,255)$. The definition of religion developed by Smith is explicitly acknowledged as Durkheimian and 
functional: 'a system of beliefs and practices that distinguishes the sacred from the profane and unites its adherents in a single moral community of the faithful' (2003, 26). Less overtly acknowledged is the aggregating nature of Smith's conceptualization of nations 'where a population is defined through processes of sanctification as a community of shared faith or belief $(1996,586)$. For all its efficacy as an identifier, the idea that the adherents of a religion unite in a single community of the faithful remains analytically problematic. Marzouki, McDonnell, and Roy (2016) assert in their study of resurgent right-wing populism that far-right nationalists across the developed world 'hijack' religion for their own ends. Such populist political actors claim allegiance to their nation's historical religion, whilst standing at odds, in both political and theological terms, with most of those who practice the religion in question or lead its practicing community. To count these diverse groups as a single community of the faithful on the grounds that they all claim allegiance to a given faith, despite their differing attitudes to the relationship between nation and religion, can impair our understanding of that relationship.

Smith addresses this analytical complexity by distinguishing between, on the one hand, an instinctual amalgamation of national identity, ethnicity, and popular religion adhered to by 'the people' as a whole; and on the other, designations of religion at the level of the national leadership. The two phenomena that Smith refers to as 'popular expressions and manifestations of religious sentiments' and the 'religiously inflected nationalisms' promoted by 'nationalist regimes and leaders' (2003, 29), I call here reflexive religio-nationalism and reasoned religionationalism. Even this bifurcation is not sufficiently precise to capture the complexity of the relationship between religion and nation. Reasoned religio-nationalism refers to a considered case being made with the aim of expounding and reinforcing the relationship between religion and nation. Its grounding is intellectual, as opposed to the instinctual basis of reflexive religionationalism. This article proposes, through consideration of the relationship between Russian 
Orthodoxy and Russian nationalism, a further delineation of reasoned religio-nationalism, distinguishing between perspectives from either end of the nationalist-religious spectrum. At the nationalist end of that spectrum, the expatria rationale for reinforcing the relationship between religion and nation begins with nationalism and incorporates religion as a secondary aspect supporting that nationalism. Those who start from there define their relationship to religion from a position of nationalism. For others, at the religious end of the nationalist-religious spectrum, their starting point is the religious. The ex religio rationale expounds the association of religion with the nation from the position of a believer for whom faith comes first. Their relationship to the nation is worked out from a position of religious adherence. Figure One depicts the three sub-categories of religio-nationalism considered in this article.

[Figure One about here]

The case-based hypothesis of this article is that considering the relationship between Russian Orthodoxy and the Russian nation from an Orthodox theological and philosophical perspective reveals a markedly different standpoint than is found when starting from a political, nationalist perspective that takes little or no account of Orthodox doctrine or practice. In considering the political ambivalence of religion, Daniel Philpott concludes bluntly that 'religion matters'; that is, the content of a religion, its doctrine and practice and theology of politics. He argues that although a religion's political theology does not of course explain the relationship between religion and nationalism in toto, specifically religious motivations differ from those based purely on identity $(2007,522)$. Applying Philpott's insight to our exploratory case, a theo-political consideration of Russian Orthodoxy's relationship with nationalism provides an account of Russian nationalism that is different from that offered by those for whom Orthodoxy represents an identity rather than a faith expressed through religious observance. Specifically, such a theopolitical consideration seems less likely to develop an antagonistic and axiologically combative attitude to the non-Russian world. This article's normative position is that a theo-political 
approach to Russian nationalism, drawing on a range of Orthodox thinkers and doctrinal statements, has the potential to deepen understanding of the relationship of Orthodoxy as Christian belief to the concept of national identity, and in this way to reduce nationalism's more conflictual aspects and deepen the peaceable influence situated within Russian Orthodoxy itself. I proceed by identifying the distinct contexts within which Orthodox and national identity are seen to overlap. The first of these consists of what I termed above reflexive religionationalism - in this case, the popular notion held by the majority of Russians that to be Russian is to be Orthodox. Such a notion does not demand detailed justification, but stems from selfidentification drawing primarily on history and culture, ethnicity and territoriality. Karpov, Lisovskaya, and Barry (2012) have developed the concept of 'ethnodoxy' to analyze this instinctual overlap of ethnicity and religion. The second context is what I identify as reasoned religio-nationalism, following Smith's distinction between popular and what he calls 'élitesponsored' designations of nationalism and religion (2003, 28-29). Within reasoned religionationalism I distinguish two distinct strands-the nationalist expatria strand, and the faith-based ex religio strand. The term 'strand' speaks here of the insistence that religion and nationalism represent distinct categories. Following Rogers Brubaker, 'nationalism and religion are often deeply intertwined ... Yet intertwining is not identity: the very metaphor of intertwining implies a distinction between the intertwined strands' (Brubaker 2012, 16). Both of these strands are concerned with elaborating and elucidating the relationship between religion and nation; they differ in that the nationalist expatria strand starts with nationalism and from there works out its relationship with religion, whereas the ex religio strand starts with religion and from there works out its relationship with the nation. A similar distinction between 'religion as an identity phenomenon and religion as a values-based phenomenon' can be found in the work of Marzouki, McDonnell, and Roy (Patrikios 2017). They concentrate their analysis on the 
nationalist strand across Europe, Israel, and the United States. I focus on the religious strand and the Russian context.

This ex religio strand forms the principal part of this article and comprises those who would be identified as within the broad Russian nationalist camp, but whose perspective starts with Orthodoxy and works from there to nationalism. Within this strand I follow Smith in a focus on national leaders $(2003,29)$; those whose line of reasoning might be most readily identified as close to that of the contemporary Russian authorities - that is the Russian Orthodox Church itself and the three Orthodox philosophers singled out by the Kremlin under Vladimir Putin for particular study and acknowledgement, namely Vladimir Solovev (1853-1900), Nikolai Berdyaev (1874-1948), and Ivan Il'in (1883-1954). In contrast to this ex religio perspective, the nationalist expatria strand exists within what has become known as 'political Orthodoxy'. Here nationalist political groups identify with Russian Orthodoxy and have developed a complex of argumentation and symbolism tying religion and nationalism together. Their position privileges the political over the religious, starting with Russian nationalism and working from there to incorporate Orthodoxy. I argue that the differing contexts within which Russian Orthodoxy and Russian nationalism come together produce different normative conceptualizations of nationalism. Too often popular, impressionistic, and journalistic accounts lump Orthodoxy and nationalism together without nuance, as if the adoption of Orthodoxy by nationalist political groups is a representation of Orthodox belief in toto. A focus on perceptions of Russian nationalism that proceed from a religious perspective offer a more nuanced and less antagonistic account of the relationship between Russian Orthodoxy and Russian nationalism.

Andrew F. March's elaboration of comparative political theory provides important methodological context, particularly with regard to his emphasis on 'engaged comparative political theory' (2009, 531). March insists that comparative political theory must consist of more than merely writing about non-Western texts as a nod towards 'expanding the canon' and 
demonstrating that we are aware of other writings alien to 'our' approaches. Instead, the comparative approach ought to be of the first order, engaging with the content of ideas beyond Western writers for the sake of the ideas themselves and their contribution to our understanding of a debate, not as an intellectual curiosity at which to point and imply that somehow they do things differently there. The Russian example is chosen because Russian Orthodoxy provides as I argue later on the back of public opinion data and the writings of other western scholars-a clear example of the expatria and ex religio strands of reasoned religio-nationalism in play. In line with March's approach, there is no 'othering' of Russia intended here. The assertion is that the tool developed in this article, of distinguishing between expatria and ex religio reasoning in analysis of religio-nationalism, might prove useful for scholars of nationalism, period; not that it is only appropriate for a one-off conceptualisation of the Russian case alone.

\section{Reflexive Religio-Nationalism-Ethnodoxy}

To return to the definitional question, often what is meant by religion relates not to lived faith or accepted doctrine, but rather to an identity similar to ethnicity that is inherited from birth. For example, to be a Turk is to be a Muslim and to be Russian is to be Orthodox. Religion serves as a marker of the boundary between groups, regardless of the actual content of the religion. Instead of orthodoxy, in the literal sense of 'correct doctrine', we are dealing here with what Karpov, Lisovskaya, and Barry term 'ethnodoxy', defined as

a belief system that rigidly links a group's ethnic identity to its dominant religion and consequently tends to view other religions as potentially or actually harmful to the group's unity and well-being and, therefore, seeks protected and privileged status for the group's dominant faith $(2012,644)$. 
The concept of ethnodoxy draws on the notion of popular religiosity (Lippy 1994), and distinguishes itself from orthodoxy by its loose relationship with formal doctrine. Ethnodox belief consists of a syncretic fusion of ideas that may draw on the doctrines associated with the dominant religion, or may be at odds with them. The unformalized nature of popular religion means that it is not uncommon for contradictory beliefs to be held, for example, superstitions with pagan roots incorporated within adherence to Christianity. Karpov, Lisovskaya, and Barry chose Russia as the test case for empirical endorsement of their concept of ethnodoxy. They justify the choice of Russia as the case study on the grounds of the close interplay between ethnonational and religious identities in that country' (2012, 645). In $2015,57 \%$ of Russians said that being Orthodox is an important part of being truly Russian, with even a quarter of Muslims and the non-religious agreeing that this is the case (Pew Research Center 10 May 2017, 12).

When measuring religious belief, researchers seeking to ascertain the level of religiosity amongst a particular group—for example, the population of a given country—may simply ask people what faith, if any, they adhere to. A more tightly defined approach would be to ask how often people attend religious services, although studies in the United States have demonstrated that respondents tend to exaggerate the frequency of such attendance in social contexts where observance is deemed laudable (Norris and Inglehart 2004, 91). In the case of Russia and its status as an Orthodox country, opinion poll data are in line with ethnodoxy. In 2016 80\% of Russians self-identified as Orthodox believers, with the remainder being split between nonbelievers and believers in other religions. At the same time, only $6 \%$ of respondents said that they attended a religious service even once a month (Levada Center 2017, 167). Not only is it probable that this latter figure is an exaggeration, but also that figure of $6 \%$ includes believers of other religions, amongst whom regular attendance at religious services is likely to be comparatively higher than amongst the Orthodox due to the commitment implicit in following a minority religion. Scholarly analysis from 2009, when opinion polls were reporting monthly 
church attendance at around 7\%, estimated that the actual figure for the number of Russians 'attending church on a regular basis' was around 0.5\% (Mitrokhin, Nuritova, and Kishkovsky $2009,290)$. What we see in Russia is a remarkable gap between the number of people who identify as Orthodox believers, and the number who regularly attend Orthodox services.

The predominantly ethnodox nature of belief across the Russian population stands as the first contextual factor to be identified in our consideration of the relationship between religion and nationalism from the theological and philosophical perspective. For most Russians, who do not engage to any great extent in either religion or politics, Orthodoxy and national patriotism are part of the same package. Believers' self-designation as Orthodox and patriotic represents a largely intuitive and self-evident position; it is part of being Russian. This is what I term reflexive religio-nationalism.

I turn now to the second context for consideration of the relationship between religion and nationalism, namely, reasoned religio-nationalism. This is when a considered case is made with the aim of expounding and reinforcing the relationship between religion and nation. The two strands of reasoned religio-nationalism that I identify here are the nationalist expatria strand, and the faith-based ex religio strand. Both concern themselves with explaining the relationship between religion and nation; the expatria strand starts with nationalism and from there works out its relationship with religion, the ex religio strand starts with religion and from there works out its relationship with the nation.

\section{Reasoned Religio-Nationalism-the Nationalist ex patria Strand}

The nationalist strand of reasoned religio-nationalism consists of what has been termed 'political Orthodoxy' (Verkhovskii 2003; Mitrofanova 2005), and is made up of those people who seek to 
articulate and justify a connection between Russian Orthodoxy and Russian nationalism, but who do so from an explicit nationalist and political position, rather than from a theo-political perspective. In perhaps the most detailed account of political Orthodoxy published so far in the West, Russian scholar Anastasia Mitrofanova has provided a useful typology in an attempt to bring some order to the numerous nationalist political actors laying hold of the designation 'Russian Orthodox'. Amongst these groups and individuals, various sub-groups distinguish themselves by different geopolitical and ideological emphases.

Mitrofanova identifies five versions of political Orthodoxy—pan-Slavism, Eurasianism, Orthodox Communism, quasi-Orthodoxy, and political fundamentalism (2005, 37-74). The panSlavist and Eurasianist groupings within political Orthodoxy stress Russian nationalism's geopolitical and civilizational aspects. From this perspective Orthodoxy fills the role of a unifying and distinctively non-Western spiritual element within nationalism. Contemporary panSlavism holds to the notion of a pan-Slavic Orthodox civilization, headed by Russia and including Belarus, Ukraine, and Serbia. Eurasianism on the other hand looks South and East, rather than towards Russia's Orthodox neighbors to the West, emphasizing Russia's Asian landmass and identity. Eurasianists believe that the Russian Federation occupies a pivotal place in the world both geopolitically and in civilizational terms. In short, they see Russia as offering an alternative superior to the West. Eurasianists embracing Orthodoxy identify themselves as having far more in common with what they would call other traditional faiths-notably Islam, and principally Shi'a Islam—-than with other Christian churches. The Putin presidency has, at arm's length, dabbled with Eurasianist ideas, through links with the Izborsky Club think-tank (see Laruelle 2016).

Three further streams of Orthodox nationalism are identified by Mitrofanova in line with their distinctive ideological positions-Orthodox Communism, quasi-Orthodoxy, and political fundamentalism. Orthodox Communists have dropped their former aggressively atheist stance 
and embraced Russian Orthodoxy as a marker of their nationalist position. The leader of the Communist Party of the Russian Federation (CPRF) has written of Jesus's Sermon on the Mount as being identical to the 'moral code of the builder of Communism' (Zyuganov 2011). Beyond the CPRF, many 'national Bolsheviks' adhere to a strange mix of Russian Orthodox and Soviet symbolism; red banners including the image of Jesus are not uncommon at their demonstrations.

Whilst conservative nationalism sits a little incongruously in the ideological armory of a formerly leftist and internationalist Communist movement, it has a more comfortable fit amongst the skinhead groups, nationalist martial arts clubs, and similar street-level practitioners of contentious politics that form part of Russia's youth sub-culture. What Mitrofanova labels 'quasiOrthodoxy and neo-paganism' $(2005,66)$ represents in some ways the logical conclusion of the idea that to be Russian is to be Orthodox, and the logical extension of a reasoned expatria explanation of religio-nationalism that begins with the national and proceeds to the religious. Orthodoxy is 'the religion of the Russian people', and so whatever the religion of the Russian people is, that is what Orthodoxy is. From this perspective, traditional pagan ideas, neopaganism, ethnic Orthodoxy, even notions of Russians as the Aryan ideal and racially superior, are all subsumed into a quasi-Orthodoxy that bears little relation to Orthodox doctrine or practice.

Of the versions of political Orthodoxy identified by Mitrofanova, the closest to the Russian Orthodox Church authorities themselves is what she terms 'political fundamentalism' $(2005,37)$. Even this version of political Orthodoxy, despite many of its ideas being associated with the late Metropolitan Ioann (1927-95), has been condemned by the hierarchy of the Church. Groups within this stream embrace notions of Russia's messianic destiny and of the Russian people as a Chosen People, destined for salvation in the face of an apostate modern (for which read Western) world. Ioann was appointed Metropolitan of St Petersburg and Ladoga—the second most important position in the Russian Orthodox Church—during the confusion of the late 
Soviet era, as the Church emerged from decades of persecution and state control. However, the Patriarch 'was soon to regret this promotion of Ioann to such a prominent position ... [and] issued a directive banning Ioann from publishing his views in the Moscow patriarchate's publications' (Corley 1995).

For the purposes of this paper, the two points to emphasize in relation to the different streams of political Orthodoxy are first, that they are for the most part separate from and even antagonistic towards the Russian Orthodox Church as an institution; and second, that they are backed by well-developed ideological stances expounded in multiple texts by the movements' ideologues. On the first of these points, Irina Papkova notes that fundamentalist groups that have taken leading roles in political activism are 'decidedly lay in character', but nonetheless it is these fundamentalists who 'come closest to fitting the parameters usually associated by Western observers with the political platform of the church as a whole' (2011, 65-66). The second key point — that political Orthodoxy has a well-developed ideologically focused literature supporting it—serves to distinguish the political Orthodox from the large majority of what I called above, following Karpov, Lisovskaya, and Barry (2012), ethnodox believers.

\section{Reasoned Religio-Nationalism-the ex religio Strand.}

The argument-based aspect of political Orthodoxy leads us to the central element of the current article. If most of those who identify as Russian Orthodox believers have a reflexive rather than a reasoned understanding of the faith and its relationship to nationalism; and if the political Orthodox, a movement often antagonistic to and largely disowned by the Russian Orthodox Church, are the source of much ideological and mass media output on the relationship between Orthodoxy and Russian nationalism; then what of formal positions put forward by the Russian Orthodox Church, and even philosophical positions promoted by the Russian state, regarding the relationship between Orthodoxy and nationalism? 
So far I have considered this relationship between Russian Orthodoxy and Russian nationalism from two perspectives. The first one-that of the majority of Russian people for whom the Orthodox faith serves as a marker of belonging to the Russian nation-operates at the intuitive level rather than being a carefully reasoned intellectual position. The second one-that of the political Orthodox — has a reasoned expatria rationale stemming from and motivated by the political side of the Orthodoxy-nationalism balance rather than from the religious side. What is missing then is an ex religio explanation of the relationship between these two elements, an explanation that starts with the religious rather than with the political. An account of how Russian Orthodoxy relates to Russian nationalism that is situated within a theo-political context offers this previously neglected perspective. Hypothesizing that a primarily faith-based rationale might conceptually prefer unity over division, inclusivity over exclusivity, and benevolence over animosity, such a perspective allows for an Orthodox correlation with nationalism that is less antagonistic in its relationship to the Western world than the examples of political Orthodoxy explored above.

Endorsing Philpott's observation $(2007,522)$ that in considering religion's relationship with nationalism, the content of religion matters, I begin analysis of the ex religio strand of religionationalism in Russia by considering Russian Orthodox doctrine. From the perspective of political theology, the central dilemma at the heart of the relationship between the Russian Orthodox Church and Russian nationalism relates to the Christian doctrine of the 'church universal'. The problematic here is both ecclesiological and soteriological. In short, if, theologically speaking, salvation is for people from all nations who come together as the church of Christ; and if there is no distinction between nationalities, since 'there is neither Jew nor Greek ... for you are all one in Christ' (Galatians 3:28, NASB); what then is the theological justification for a national church? Or, more pertinently and in a stronger variant, for a national church that might take a nationalist stance, such as the privileging of one nation over another? Establishing the Russian Orthodox Church's 
official position on this and other socio-political questions entails a reading of its formal political theology, as elaborated in the Bases of the Social Concept of the Russian Orthodox Church (hereafter, the Social Concept), adopted at the Sacred Bishops' Council of the Russian Orthodox Church in August 2000 (Moscow Patriarchate 2000).

\section{The Social Concept of the Russian Orthodox Church.}

Where scholars have written on the official theo-political position of Russian Orthodoxy, their analyses are largely situated outside of the Western theo-political mainstream and oriented more to an area or denominational focus (Knox 2003; Petrunin 2009; Stöckl 2006; 2010), with the partial exception of Agadjanian's (2003) comparative approach considering the Social Concept alongside the Catechism of the Catholic Church. Agadjanian terms the Social Concept 'an intrinsically torn and polyphonic document' $(2003,339)$. Tensions exist in the theologically difficult area of holding onto Christian universality at the same time as asserting territorial and denominational preeminence. The theological significance of this issue lies in concerns which are primarily ecclesiological, surrounding the universality of Christ's church and its calling to all the nations. It would be a mistake, however, to see such theological questions as esoteric and of little practical significance in the political world. Take, for example, the case of the all-female radical punk band Pussy Riot, arrested and imprisoned in 2012 after performing an expletive-laden song in Moscow's Cathedral of Christ the Saviour, protesting against the links between the Russian Orthodox Church and Russia's political leadership. Much of the discourse surrounding the case-and illustrated in the writings of, for example, the pro-Kremlin political commentator Sergei Markov and the nationalist Aleksandr Dugin (Markov 2012; Weir 2012)—alleged the actions of Pussy Riot to be an attack not only on the Church but also on Russia itself. These two commentators can be seen, respectively, as illustrative of the ethnodox and the political Orthodox approaches explored above. What then of the Church's theo-political stance? 
The Social Concept of the Russian Orthodox Church declares that 'the Church by her very nature is universal and therefore supranational', that the Christian has a 'right to national identity and national self-expression', and that 'the Church unites in herself the universal with the national' (Moscow Patriarchate 2000, II, 1-2). It explicitly seeks scriptural justification for its stance, thereby emphasising the status of the Russian Orthodox Church as part of the wider community of faith, the Christian church, that bases its doctrinal positions on the Bible. The interpretation of biblical passages, however, — as with many a canonical text whether religious or secular — will always remain contestable. The Social Concept, in line with traditional Eastern Orthodox theology, cites Jesus's injunction to 'render to Caesar the things that are Caesar's; and to God the things that are God's' (Matthew 22:21, NASB) as evidence that 'Jesus was a loyal subject of the Roman Empire and paid taxes in favor of Caesar' (Moscow Patriarchate 2000, II, 2). Whilst other readings might interpret Jesus's statement as an enigmatic response to pharisaic attempts to lure him into a political trap, in the Russian Orthodox Church this particular verse has long been employed to argue in favour of loyalty to the state, including at times the atheist Soviet state (Lorgus 1992). The Social Concept proposes too an example of the Apostle Paul identifying himself with the people of his birth, positing that:

'St. Paul, in his letters teaching on the supranational nature of the Church of Christ, did not forget that by birth he was "a Hebrew of the Hebrews" (Phil. 3:5), though a Roman by citizenship (Acts 22:25-29).' (Moscow Patriarchate 2000, II, 2)

A different reading of these verses in the Letter to the Philippians would note that St. Paul was famous for rejecting the obligations of the Jewish faith and would emphasize his assertionimmediately following the sentence quoted in the Social Concept-that, despite impeccable ancestry and credentials in terms of Jewish ethnicity and identity, 'those things I have counted as loss for the sake of Christ' (Philippians 3:7, NASB). Using a scriptural basis, the Russian Orthodox Church's official Social Concept builds a political theology that venerates ethnic identity and 
national fervor, enjoining the Orthodox believer 'to love their homeland on earth and not to spare their lives to protect it ... to love his fatherland, which has a territorial dimension, and his brothers by blood who live everywhere in the world' (Moscow Patriarchate 2000, II, 2-3).

Historical examples are brought to the aid of this charge: Prince Michael of Tver, who 'gave his life for his fatherland'; the abbot Sergius, who blessed the troops of Dmitrii Donskoi before doing battle with the Mongol hordes in 1380; Patriarch Hermogen, who gave a blessing to the soldiers seeking to expel the Poles from Moscow in 1612, an event commemorated by a major new public holiday introduced by President Putin in 2005; and Metropolitan Philaret of Moscow, who declared during the Napoleonic wars that to die for the faith and the Fatherland was to be granted life and a crown in heaven (Moscow Patriarchate 2000, II, 2). To the Russian Orthodox Church the calling to love their homeland to the death sits within believers' heavenly calling. At the same time as asserting the supranational nature of the church, the Russian Orthodox Church upholds notions of 'Christian patriotism' and loyalty to the state (Moscow Patriarchate 2000, II, 1; II, 3; III, 5). According to the Social Concept of the Russian Orthodox Church, it is the believers' duty to love their earthly homeland and defend it with their lives. Much is made of defending Russian identity against its enemies who would destroy it.

\section{Vladimir Solovev, Nikolai Berdyaev, and Ivan Il'in.}

Although the theo-political approach to the relationship between Orthodoxy and nationalism is most self-evidently investigated through analysis of the formal theological position of the Russian Orthodox Church as set out in its Social Concept, it can also be explored through consideration of the work of those Orthodox philosophers who have received the imprimatur of the current Russian regime. Over New Year 2014 Kremlin officials and the leadership of President Putin's United Russia party gave regional leaders and party officials some holiday reading consisting of works by three renowned $19^{\text {th }}$ and $20^{\text {th }}$ century Russian philosophers, each of whom had developed 
in their writing 'the Russian idea' (Surnacheva 2014). These philosophers-Vladimir Solovev, Nikolai Berdyaev, and Ivan Il'in—all wrote at length about Russian nationalism in the context of their Russian Orthodox faith. Of course this short article cannot delve satisfactorily into so deep and detailed a resource in order to capture the richness and nuances of each writer's relationship to Russian nationalism. That is not my objective here.

The following analysis merely steps into the shallows of the writings of Solovev, Berdyaev, and Il'in, which slope away into depths of philosophical nuance and contention to encompass a myriad of questions lying beyond what this article touches. But this is not an article on any or all of this trio of Kremlin-endorsed philosophers per se. It seeks rather to contribute to theoretical understandings of the relationship between religion and nationalism by developing the distinction between expatria and ex religio reasoned conceptualisations of that relationship. That being the case, the limited intent of exploring the writings of Solovev, Berdyaev, and Il'in on the theme of religion and nationalism is to illustrate their approach to nationalism from an ex religio perspective, as in each case they balance patriotic Russian nationalism and Orthodox faith up against warnings about belligerent animosity towards other nations.

After it became known that this troika of philosophers had come to form some sort of reading list approved by the ruling regime, the New York Times summed up the multi-volume complexity of thinkers' whose work covered eight decades as pointing to 'a Russia that is a quasi-theocratic nationalist autocracy' (Brooks 2014). Even a passing consideration of the positions taken by Solovev, Berdyaev and Il'in demonstrates how their views diverge both from broad-brush description as Orthodox nationalist autocrats, and from each other. Their various positions differ too from the theological statements of the Russian Orthodox Church and its hierarchy.

Placing such a range of theological and philosophical approaches to religio-nationalism together within the same ex religio reasoned strand of religio-nationalism follows on from a similarly wide range of 'political Orthodox' positions set out earlier within the expatria reasoned strand of religio- 
nationalism. These differing examples serve to emphasize that ex patria and ex religio lines of reasoning in support of religio-nationalism represent approaches not bodies of thought. The terms ex patria and ex religio have been chosen specifically to highlight process rather than outcome, movement rather than destination. Using the Russian ex religio case to exemplify; the argument is not that Solovev, Berdyaev, Il'in, and the Social Concept of the Russian Orthodox Church represent a single set of conclusions or broadly agree with one another. In places they do, in places they do not. The argument is rather that, in the examples used here, each approaches religionationalism from the starting point of religion —actually, Russian Orthodoxy in these cases—and develops reasoned arguments with regard to how their faith informs their approach to nationalism. Such an ex religio argument, as the foregoing and following examples illustrate, tends towards a less axiologically divisive and isolating position than do reasoned arguments for religio-nationalism that precede on an expatria basis, starting with political nationalism and recruiting religion in its support.

Andrew F. March's framework for comparative political theory, noted earlier, sets out several tests for text selection. The works of Solovev, Berdyaev, and Il'in considered here fit within March's injunction that for texts to merit analysis in terms of comparative political theory they require a measure of authority within a tradition, and to represent a

semi-autonomous application of reason (which includes the interpretation of revelation) in order to provide guidance (including critique) on political and social life. The ideas themselves must be the object of our interest — even if it is only because we think they have social consequences. (2009, 553-54).

In the cases considered here, the fact of these three writers having been singled out as holiday reading for Russia's regional leaders speaks of their status. Analysis of their work need not, and does not in this article, restrict itself to the specific texts selected in this way. Solovev's The Justification of the Good happens to be the article chosen for officials' reading matter in 2014, but its text is analysed here not for that reason but because it best represents Solovev's ex religio reasoning 
about religion and nationalism. The texts of Berdyaev and Il'in considered below are selected for the same reason, but range beyond those chosen for officials' reading matter in 2014. The argument made in this article does not depend on the particular texts considered being the same as those endorsed by the Kremlin, but on the status of their authors and the relevance of the text to the subject of religion's relationship to nationalism. According to Cambridge University Press's A History of Russian Philosophy, Solovev is 'widely regarded as Russia's greatest philosopher, certainly its greatest religious philosopher' (Hamburg and Poole 2010, 131). Berdyaev and Il'in are philosophers of whom President Putin has spoken favourably in circumstances other than the 2014 reading recommendations, having quoted from both of them in his annual 'state of the nation' addresses. Their lauding by the Russian authorities marks them out as philosophers of a certain standing in contemporary Russia. Such standing, on top of the more widely recognised merit of Solovev and Berdyaev in particular, along with their commitment to Russian Orthodoxy and nationalism, reinforces their merit as appropriate texts for comparative consideration of $e x$ religio approaches to religio-nationalism.

Vladimir Solovev's lengthy essay on moral philosophy, The Justification of the Good, devoted much space to consideration of the Christian faith in relation to the nation and the state. Solovev was explicit in his ex religio approach, in a chapter entitled 'the national question from the moral point of view' he developed his thinking on nationalism through detailed scriptural exposition. It is Solovev at his most theological in approach, and writing in the full maturity of his thinking, only three years before his death. Here he is repeatedly clear from a theo-political perspective in his dismissal of national exceptionalism, arguing — to take just one example of many similar-that

Russia has decisively confirmed its profession of Christian universalism when, in the most important and glorious era of its recent history it decisively left behind national isolationism and revealed itself as a vital member of the international whole. (Solovev 1911, 467-68; translation author's own). 
For Solovev in The Justification of the Good the nation was analagous with the individual in terms of its value to God and its need for 'spiritual regeneration'.

In the "body of Christ" [that is, the church universal] individual peculiarities do not separate one person from others, but unite each with all, being the ground for his special significance for all and his positive interaction with them. Now this obviously applies to nationality as well ... Since Christianity does not demand absence of individual character, it cannot demand absence of national character. The spiritual regeneration of individuals and of nations does not mean a loss of the natural qualities and powers; it means that these qualities are transformed, that a new direction and a new content are given them. When Peter and John were regenerated by the spirit of Christ, they did not lose any of their positive peculiarities and distinctive characteristic features. So far from losing their individuality, they developed and strengthened it. This is how it must be with entire nations converted to Christianity. (Solovev [1897] 2005, 246-47)

Solovev's argument then moved beyond the relatively abstract conceptualisation of nations as analogous to individuals in terms of their valued distinctives and their need for sanctification, as he provided specific examples of nations, and nationalism, gone astray. In particular Solovev used the history of the Spanish nation to argue against a narrow nationalism leading to violence. He contended that, more than any other nation, the Spanish had 'distorted the truth of Christianity in their practical conception of it and in their actions; more decisively than anyone they associated it with violence' to such an extent that 'the spiritual sword proved in the end to be as material and violent as the worldly, though more painful and less noble than the latter' (Solovev [1897] 2005, 251). In The Justification of the Good, Solovev's ex religio development of religio-nationalism urged peace and Christ-like behaviour above violence and the use of the sword. 
Nikolai Berdyaev was much influenced by Solovev and considered his 'great service [to be] his exposure of the wrongness of nationalism' $(1948,125)$. Berdyaev wrote in theo-political terms similar to Solovev's about the relationship between the Christian faith and nationalism. $\mathrm{He}$ emphasized the tendency of many nationalists to adopt religion simply as a signifier of ethnic identity, 'as an instrument of national power', whilst denying the essence of faith. To Berdyaev, nationalism was nothing more than idolatry where 'the nation replaces God'. He argued that, although different national groups have different expressions of faith-such as Russian Orthodoxy, the Church of England, and Polish Catholicism—nationalism is 'foreign to the ideas of the Christian universalism of the Middle Ages: it is a product of modern history which has lost its sense of unity' (Berdyaev and Lowrie 1935, 87-88).

Aware of the discussions in Orthodox thought, particularly during the late Imperial era, around the relationship of the Russian Orthodox Church to the Russian state and the interpretation of Jesus's injunction to 'render to Caesar the things that are Caesar's; and to God the things that are God's' (Matthew 22:21, NASB), Berdyaev argues that —in the mid-1930s, with Stalin ruling the Soviet Union and fascism rising across Europe — 'the kingdom of Caesar' increasingly represents something 'demoniac and tyrannous'. According to Berdyaev, 'nationalism is one of the roads toward tyranny of the things of Caesar over the spirit' (Berdyaev and Lowrie 1935, 107). In his later works - he died in 1948 - Berdyaev wrote in some detail of his religious faith and of Russian Orthodoxy within the context of Christianity more widely. Such a wider perspective is apparent too in his assessment of nationalism contained in The Russian Idea (1948), where he wrote approvingly of a universal — not Russian — messianism. Developing his notion of the relationship between religion and nationalism in an ex religio manner, Berdyaev argued against narrow and isolationist nationalism, concluding that 'messianism has nothing in common with an exclusive nationalism. Messianism opens out, it does not shut off (1948, 202-03). 
The third of the trio of Russian philosophers making up the Kremlin's 'reading list' for regional officials in 2014 was Ivan Il'in. Much less well-known in the West than Solovev and Berdyaev, Il'in's theo-political philosophy brought together Russian nationalism, Orthodoxy, and a fierce anti-Bolshevism. Having taught at Moscow State University until shortly after the Bolshevik revolution in 1917, Il'in was arrested several times for his anti-Bolshevik views before being sentenced to death in 1922. This sentence was never carried out, and he was expelled from Russia on the infamous Philosophers' Ship in September 1922 with around 80 anti-communist intellectuals and their families (Chamberlain 2006, 149). As an émigré, Il'in lived in Berlin and finally, after the Nazis came to power, in Switzerland. He died in 1954. In October 2005, both Il'in and General Anton Denikin, Commander of the White Army that fought the Communist Reds in the Russian Civil War of 1919-21, were re-buried in the cemetery of the Donskoi Monastery in Moscow. The ceremony was presided over by the head of the Russian Orthodox Church, Patriarch Aleksei II, and attended by President Vladimir Putin, who quoted Il'in in his annual address to parliament in May 2006.

Central to Il'in's philosophy was the notion of spirituality. It is through this philosophical prism that he formulated a political theology of nationalism as a spiritual phenomenon. 'Nationalism', he wrote, 'is a positive and strong feeling which my people have received as a gift from the Holy Spirit' (Il'in 1993, 363). His 1937 work The Path of Spiritual Renewal —which dealt with the questions of faith, love, belief, the state, patriotism and nationalism — forms the starting point for this brief summary of Il'in's approach to nationalism. From a theo-political perspective, Il'in approached religion and nationalism differently. The first three chapters of The Path of Spiritual Renewal engage with archetypal questions of religion—faith, love, and freedom—and draw for their argument on repeated engagement with the Bible and with the Church fathers. When Il'in turned his attention, in chapters 6 and 7, to the 'rodina' (Motherland) and to nationalism, the theological content diminished markedly. 
Il'in's perspective on nationalism stood against the doctrine of universality to a degree, as he argued against those Christians who saw themselves as citizens of heaven and did not embrace the divisions of nationalism ([1937] 2012, 229-30). He linked such a denial of national identity to Bolshevik internationalism. Il'in portrayed nationalism as being more than reflexive, although he insisted that instinctual patriotism was better than no patriotism at all. He insisted too on the distinction between a positive love-based patriotism, and a patriotism that goes wrong and develops into aggression and militant chauvinism ([1937] 2012, 230-37).

For Ivan Il'in, nationalism had a deep spiritual basis and must be based on love, rather than on ethnicity or blood. Each people group, in their homeland, represented for him 'the bearer and servant of the cause of God on earth, the carrier and form of the divine' ([1937] 2012, 269). Whilst such a strong emphasis on the importance of national identity can most straightforwardly be interpreted — from a theological perspective—as being at odds with the notion of the universal church in which national distinctions mean nothing, it does also allow for a different interpretation that insists on recognizing national distinctives but retains such a perspective within the framework of the universal church and God's love for all peoples. This latter interpretation relies on Il'in's emphasis that the nationalism he professed was spiritual and love-based, and on his clear assertion that love for one's own homeland did not require that any people group be considered superior. He considered the idea of superior nations to be 'bestial nationalism' since:

\footnotetext{
'No man and no people would be the only focus of the spirit, for the spirit lives in its own way in all people and all nations. True patriotism and nationalism is not blind love, but clearsighted, and its atmosphere is not only no stranger to goodness and fairness, and law, and most importantly, the Spirit of God, but it is one of the highest manifestations of spirituality on earth' (Il'in [1937] 2012, 314).
}

Il'in's commitment to the spiritual nature of nationalism remained with him to the end. The work of Ivan Il'in that was included in the regional leaders' reading list of 2014 consisted of two volumes, 
entitled Our Tasks and made up of the collected works of Il'in's later years, when he was looking towards what must have seemed all but unimaginable to him at the time, namely the post-Soviet existence of Russia. In the very last of these collected pieces, Il'in wrote —in capital letters for emphasis- 'And the main thing is that A NEW RUSSIAN SPIRITUAL CHARACTER ARISE IN THE PEOPLE' ([1956] 2008, 359). Even this most nationalist, and least internationalist, of the three cited as Putin's philosophers maintained an ex religio approach to nationalism that argued, in a 1952 essay also contained in Our Tasks, for 'a living Christian conscience, a faith in the spirit of goodness, a sense of what is evil, a feeling of honour, and an ability to be faithful. Without this, Russia will not revive' ([1956] 2008, 63).

\section{Conclusions from a Theo-Political Reading of State- and Church-Endorsed Texts}

The culmination of our analysis has been a theo-political reading of the Russian Orthodox Church's Social Concept and of writings from the three philosophers whose stance in relation to the 'Russian idea' has been—informally at least—endorsed by Russia's political leadership under Vladimir Putin. Assessing the nature of Russian Orthodoxy's relationship with Russian nationalism through considering the reasoned ex religio approach developed and promoted by Russia's religious and secular hierarchy reveals a more nuanced and less bellicose nationalism than is to be found within the reasoned expatria discourse of the many Russian nationalist groups that assert their Orthodox identity. The religio-nationalism found in these officiallysanctioned authoritative sources critiques ideas of national superiority and emphasizes, or at least incorporates, concepts of common humanity, spirituality, and love.

A striking majority of Russians self-identify as Orthodox believers, even though comparatively few of them embrace the social science of religion's trinity—believing, behaving, belonging (Smidt, Kellstedt, and Guth 2009, 24) — when it comes to church attendance and engagement with priest and parish. Such reflexive, or ethnodox, belief often represents an instinctual sense of 
religion as an aspect of ethnicity, rather than religious belief as a carefully reasoned and-at least partly—intellectual decision. For most Russian nationalists the attraction of Orthodoxy as a marker of Russian exceptionality is apparent. For them though, an ethnodox stance does not suffice, since, as Anastasia Mitrofanova reasons:

The average person can call him or herself Orthodox without partaking of the sacraments of the Church, but Orthodox nationalists study their ideology, they read and think, and as a result are aware that identifying oneself as an Orthodox Christian means having a life within the Church. The main problem for Russian nationalists is their critical and even hostile attitude to the Orthodox Church. $(2016,108)$

Whilst an array of nationalist political actors adopt the title 'Russian Orthodox' and embrace notions of national glory, xenophobia, and even ethnic superiority, the formal stance of the Russian Orthodox Church when it comes to nationalism remains too rarely explored. Its political theology, as set out in the Social Concept, seeks to balance a belief in the church universal with a commitment to Russia. The Social Concept contains elements that glorify war in defense of this temporal homeland, but attempts to hold its patriotic position alongside an awareness that 'national sentiments can cause such sinful phenomena as aggressive nationalism, xenophobia, national exclusiveness and inter-ethnic enmity' (Moscow Patriarchate 2000, II, 4).

Although the Russian state is constitutionally secular, Russia's ruling regime since the collapse of the Soviet Union has sought to employ Russian Orthodoxy within its national-patriotic discourse. The nationalist stance of the Putin regime has increased over the years since Vladimir Putin became president in 2000, and particularly so since the annexation of Crimea in 2014. As the brief assessment of the writings of Solovev, Berdyaev, and Il'in illustrates, however, any veneration of these Orthodox and patriotic philosophers by the Putin regime in furtherance of 'Orthodox nationalism' must contend with the fact that their philosophies contain more nuance than is often acknowledged (see also, Laruelle, 2017). For the most part, the positions of the 
Social Concept and of those philosophers informally endorsed by Russia's political leadership are not at odds with the Russian state's adoption of a national-patriotic discourse whilst denouncing the excesses of extreme nationalism. Nonetheless, should the Russian state seek to push beyond the metaphorical—and literal—boundaries of standard state nationalism, it becomes less easy to claim their theological and philosophical backing. Vladimir Solovev argued for Christian universalism and internationalism rather than national isolationism. Nikolai Berdyaev decried the adoption of religion for the purposes of ethno-nationalism. Even Ivan Il'in - the most nationalist and least well-known internationally of this trio of Russian philosophers - argued that the promotion of national superiority amounted to 'bestial nationalism' (Il'in [1937] 2012, 314).

Beyond the specific context of the Russian case, the methodological requirement for definitional precision when considering the religion-nationalism nexus stands reinforced. Differing conclusions arise about the nature of religion's relationship with varieties of nationalism dependent on how researchers utilize the concept religion. Ethnodox conceptualizations of reflexive religio-nationalism, according to which an ethnic group and its majority confession are considered interchangeable, produce different interpretations of how that religion relates to nationalism than does analysis of reasoned argumentation elaborating a specific stance on the religion-nationalism relationship. Such a conclusion has long been understood (Smith 2003, 29). Further though, within reasoned development of the nationalism-religion relationship, I have identified two strands; the expatria strand starting from nationalism and proceeding to religion, and the ex religio strand starting from religion and proceeding to nationalism. Some nationalists may adopt religion as an indicator of national identity, whilst their convictions, actions, and factions lie outside that religion's accepted doctrine, praxis, and community of practitioners. The function and content of their religion may then diverge from that of co-religionists whose religion embraces the established teaching, practice, and kinship groups of the religion as a 
whole, and whose stance with regard to nationalism may also differ. The hypothesis that a primarily faith-based rationale tends to orientate towards unity rather than division, inclusivity rather than exclusivity, and benevolence rather than animosity has been born out in our exploratory case of Russia. Such a finding coincides with the wider comparative conclusions of Marzouki, McDonnell, and Roy (2016), who note the commonly held view of church leaders that religion has been hijacked and abused by nationalists in the specific examples that they study. Their volume ranges widely across the northern hemisphere for its cases—-the United States, Israel, and Europe East and West—and its analytical focus is on the reasoning that stems from nationalism more than from religion. The findings presented here provide a specific account concentrating in particular on the religious reasoning around nationalism in Russia. Whether the findings are sufficiently robust to be further generalizable waits on more extensive comparative research. 


\section{References}

Agadjanian, Alexander. "Breakthrough to Modernity, Apologia for Traditionalism: The Russian Orthodox View of Society and Culture in Comparative Perspective." Religion, State, and Society 31, no. 4 (2003): 327-46.

Berdyaev, Nikolai, and Donald Alexander Lowrie. The Fate of Man in the Modern World ... Translated by Donald A. Lowrie. London: Student Christian Movement Press, 1935.

Berdyaev, Nicolas. The Russian Idea. New York: The Macmillan Company, 1948

Brooks, David. "Putin Can’t Stop.” New York Times, 4 March 2014, 23.

Chamberlain, Lesley. The Philosophy Steamer: Lenin and the Exile of the Intelligentsia. London: Atlantic, 2006.

Corley, Felix. “Obituary: Metropolitan Ioann.” The Independent, 11 November 1995.

Hamburg, G. M. and Randall A. Poole (eds) A History of Russian Philosopby 1830-1930. Cambridge: Cambridge University Press, 2010

Il’in, Ivan A. Sobranie Sochinenii. Vol. 3, Moskva: Russkaya kniga, 1993.

Il’in, Ivan. Nashi zadachi: stat'i 1948-1954 gg. Tom vtoroi. Moscow: Airis Press, [1956] 2008

Il'in, Ivan. A. Put' Dukhovnogo Obnovleniya. Moscow: Pravoslavnyi izdatel'stvo Apostol Very, [1937] 2012.

Karpov, Vyacheslav, Elena Lisovskaya, and David Barry. "Ethnodoxy: How Popular Ideologies Fuse Religious and Ethnic Identities." Journal for the Scientific Study of Religion 51, no. 4 (2012): 638-55. 
Knox, Zoe. “The Symphonic Ideal: The Moscow Patriarchate’s Post-Soviet Leadership.” Europe Asia Studies 55, no. 4 (2003): 575-96.

Laruelle, Marlène. “ The Izborsky Club, or the New Conservative Avant-Garde in Russia.” The Russian Review 75 (2016): 626-44.

Laruelle, Marlène. 27 March 2017. “In search of Putin’s philosopher.” Intersection, http://intersectionproject.eu//article/politics/search-putins-philosopher (accessed May 23, 2017).

Levada Center. 2017. Obshchestvennoe mnenie 2016 - ę̧hegodnik. Moscow: Analiticheskii Tsentr Yuriya Levady.

Lippy, Charles H. Being Religious, American Style: A History of Popular Religiosity in the United States. Contributions to the Study of Religion,. Westport, Conn.: Greenwood Press, 1994.

Lorgus, Andrei “Kesaryu kesarevo: istoricheskaya apologiya” Zhurnal Moskovskoi Patriarkhii, $11-12(1992)$

March, Andrew F. "What Is Comparative Political Theory?” The Review of Politics, 71, no. 4 (2009): 531-65

Markov, Sergei. “Svoboda Bez Dobra_Eto Zlo.” Nezavisimaya gazeta, 20 August 2012, 3.

Marzouki, Nadia, Duncan McDonnell, and Olivier Roy. 2016. Saving the people: how populists hijack religion. London: C Hurst \& Co Publishers Ltd.

Mitrofanova, Anastasia V. The Politicization of Russian Orthodoxy: Actors and Ideas. Stuttgart: Ibidem, 2005. 
Mitrofanova, Anastasia V. "Russian Ethnic Nationalism and Religion Today." In The New Russian Nationalism: Imperialism, Ethnicity and Authoritarianism, 2000-15, edited by Pål Kolstø and Blakkisrud. Helge. 104-31. Edinburgh: Edinburgh University Press, 2016.

Mitrokhin, Niklolay, Aziza Nuritova, and Sophia Kishkovsky. "The Russian Orthodox Church in Contemporary Russia: Structural Problems and Contradictory Relations with the Government, 2000-2008.” Social Research: An International Quarterly 76, no. 1 (2009): 289_ 320.

Moscow Patriarchate. "Basis of the Social Concept of the Russian Orthodox Church." https://mospat.ru/en/documents/social-concepts/.

NASB. New American Standard Bible. Grand Rapids, MI: Zondervan, 2002.

Norris, Pippa, and Ronald Inglehart. Sacred and Secular: Religion and Politics Worldwide. Cambridge: Cambridge University Press, 2004.

Papkova, Irina. The Orthodox Church and Russian Politics. Washington D.C.: Woodrow Wilson Center Press; New York: Oxford University Press, 2011.

Patrikios, Stratos. 2017. "Book Review: Saving the People: How Populists Hijack Religion by Nadia Marzouki, Olivier Roy and Duncan McDonnell (eds).” Political Studies Review, http://journals.sagepub.com/doi/pdf/10.1177/1478929917706657 (accessed May 23, 2017).

Petrunin, Vladimir. Politicheskii Isikhazm i ego Traditsii v Sotsial'noi Kontseptsii Moskovskogo Patriarkhata. Saint Petersburg: Aleteiya, 2009.

Pew Research Center. 2017. Religious Belief and National Belonging in Central and Eastern Europe: National and religious identities converge in a region once dominated by atheist 
regimes. In Pew-Templeton Global Religious Future project, http:/ /assets.pewresearch.org/wpcontent/uploads/sites/11/2017/05/15120244/CEUP-FULL-REPORT.pdf (accessed May 23, 2017).

Philpott, Daniel. 2007. "Explaining the Political Ambivalence of Religion." The American Political Science Review no. 101 (3):505-25.

Smidt, Corwin E., Lyman A. Kellstedt, and James L. Guth. The Oxford Handbook of Religion and American Politics. New York; Oxford: Oxford University Press, 2009.

Smith, Anthony D. 1996. "LSE Centennial Lecture: The Resurgence of Nationalism? Myth and Memory in the Renewal of Nations." The British Journal of Sociology no. 47 (4):575-98.

Smith, Anthony D. 2003. Chosen peoples: Sacred Sources of National Identity Oxford; New York: Oxford University Press.

Solovev, Vladimir Sergeyevich. Sobranie Sochinenii Vladimira Sergieevicha Soloveva. 2. ed. 10 vols St. Petersburg: Knigoizdatel'skoe tovarishchestvo "Prosvieshchenie”, 1911.

Solovev, Vladimir Sergeyevich and Nathalie A. Duddington (translator). The Justification of the Good: An Essay on Moral Philosophy Grand Rapids Michigan: William B. Eerdmans Publishing, [1897, translation 1918] 2005

Stöckl, Kristina. "Modernity and Its Critique in 20th Century Russian Orthodox Thought." Studies in East European Thought 58, no. 4 (2006): 243-69.

Stöckl, Kristina. “Political Hesychasm? Vladimir Petrunin's Neo-Byzantine Interpretation of the Social Doctrine of the Russian Orthodox Church." Studies in East European Thought 62, no. 1 (2010): 125-33. 
Surnacheva, Elizaveta. “Chinovnikam Veleno Poluchit' Filosofiyu.” Kommersant vlast', 20 January 2014, 22-23.

Verkhovskii, Aleksandr. Politicheskoye Pravoslavie: Russkiye Pravoslavnye Natsionalisty i Fundamentalisty, 1995-2001 Gg. Moscow: Informatsionno-analiticheskii tsentr Sova, 2003.

Weir, Fred. "How Russia Transformed Pussy Riot into International Cause Célèbre.” 20 August 2012, http://www.csmonitor.com/World/Europe/2012/0820/How-Russiatransformed-Pussy-Riot-into-international-cause-celebre-video (accessed May 23, 2017).

Zyuganov, Gennadii. “'Christ Was the First Communist'-Communist Party Leader.” Russia Today, 22 April 2009, https://www.rt.com/politics/christ-first-communist-communistparty-leader/ (accessed May 23, 2017). 